Relations industrielles

Industrial Relations

\title{
The Cancellation of a Labour Contract
}

\section{Georges-Michel Giroux}

Volume 4, numéro 9, mai 1949

URI : https://id.erudit.org/iderudit/1023970ar

DOI : https://doi.org/10.7202/1023970ar

Aller au sommaire du numéro

Éditeur(s)

Département des relations industrielles de l'Université Laval

ISSN

0034-379X (imprimé)

1703-8138 (numérique)

Découvrir la revue

Citer cet article

Giroux, G.-M. (1949). The Cancellation of a Labour Contract. Relations

industrielles / Industrial Relations, 4(9), 83-87. https://doi.org/10.7202/1023970ar

Tous droits réservés (C Département des relations industrielles de l’Université Laval, 1949
Ce document est protégé par la loi sur le droit d'auteur. L'utilisation des services d'Érudit (y compris la reproduction) est assujettie à sa politique d'utilisation que vous pouvez consulter en ligne.

https://apropos.erudit.org/fr/usagers/politique-dutilisation/ 
his collaborators; but it follows that the material well-being of all the members of the nation which is the aim of social economy - obliges him more than the others to contribute to the increase of national assets by savings.

Just as one must not forget that is of supreme benefit to a sound social economy that this increase in assets should come from as many sources as possible, it is also greatly to be desired that the workers, too, should be able, as a result of their savings, to share in the building up of national assets.

Many men of industry, non-Catholics and Catholics such as you, have at various times expressly declared that the social doctrine of the Church - and that doctrine alone - is capable of providing the essential elements for a solution of the social question.
Undoubtedly, the putting into practice of this doctrine cannot be done in a day. Its realization requires of all wisdom, perspicacity and foresight, together with a large amount of common sense and good will. It requires of them, above all, a radical resistance to the temptation of each working for his own advantage at the expense of the others - regardless of the nature and form of their participation - or at the expense of the common good. It requires that altruism which only true Christian virtue, strengthened by the help and grace of God, can inspire.

To bring this help and grace on your association and its internal growth and external diffusion - particularly in those countries which even though Catholic need however to give wider consideration to the social teaching of the Church We give, with all the effusion of Our heart, to yourselves and your association, and under the powerful patronage of the Mother of Divine love, Our Apostolic Blessing.

\title{
THE CANCELLATION OF A LABOUR CONTRACT
}

\author{
Georges-Michel Giroux
}

The repeal of the Masters and Servants Act (R.S.Q., 1941, chapter 328) enacted by the Statute 13, George VI, Chapter 69, has modified the rules on the concellation of a labour contract. Many facts may extinguish the obligations resuiting from this contract, such as: mutual agreement, death of the employee (Civil Code, Art. 1668). The unilateral will of one of the parties may also terminate it; there is then cancellation of the labour contract.

To consider the concellation of the contract, it is necessary to analyze the rules on its duration and those on the term of notice; it is also necessary to examine the character of the provisions on the term of notice and the effect of the labour regulations on this subject.

\section{I - Duration of the curtract}

Anyone may, when it so pleases him, terminate a labour contract that binds him to another, it is quite obvious; an employer cannot be obliged to hire an employee and the latter, to work for an employer; memo ad actum cogi potest. The Canadian Labour Relations Board, under the rules of the Industrial Relations and Disputes Investigation Act (Canada, 11-12, George VI, chapter 54 ), may order an employer to take back in his employ, employees dismissed unjustly, (art. 40, 2); but the employer, if he does not conform to the Order only incurs penalties (art. 40, 3). An employee, even on the order of the Canadian Labour Relations Board, cannot work for an employer against the latter's will.

However, the legislator has determined the time in which the labour contract may be legally concelled by the will of one party and has ensured the injured party of an indemnity when the other party has improperly cancelled it. The law, and this is private law and not public law, wishes to ensure the respect of what has been agreed upon; it guarantees the maintenance of the engagement for the term, determined or determinable, fixed by the parties. The study of the cancellation of the labour contract leads to the examination of the legal rules on the duration.

The parties may decide on the duration of this contract:

a) for a definite term (C. C. art. 1667); 
b) for the duration of a determinate undertaking (Id.);

c) for an indefinite term (Id. art. 1668);

d) on trial.

Employees in the building construction industry usually hire themselves for the duration of a definite undertaking; brick-layers hire their services for the time necessary to the erection of the walls.

Our Civil Code, like the French Code, at the time of its adoption, did not make any provision for hiring for an indefinite period of time, but only for a fixed period. The economy and the customs of that time permitted the guarantee to employees of the security of their employ. Even at the beginning of the century, in commercial undertakings, right after the inventory, engagements were discussed and signed for the year. But now these proceedings hardly exist and the employer no longer guarantees the duration of employment.

One cannot be hired for a fixed term, except in so far as this has been agreed upon. The stipulations in regard to the duration must not be confused with those on the length of the pay period or on those of the method of calculating the wages. The hiring, at so much per year ${ }^{1}$, does not necessarily mean hiring for a year, but means the employee will have the right to claim for his work a remuneration in proportion to that fixed for a year.

The length of the pay period does not in itself determine the duration of employment. ${ }^{2}$ This is what the legislator expresses in the second paragraph of the article 1668 of the Civil Code ${ }^{3}$ in referring to "a domestic, servant, journeyman or labourer hired by the week, the month or the year, but for an indefinite period of time...

The contract for a fixed term becomes automatically renewed at its expiration for a similar term; this is the tacit renewal enacted by article 1667 of the Civil Code.

The Code, prior to the amendment of article 1668 ignored the contract for an indefinite term. «One has interpreted», said Judge Rinfret ${ }^{4}$, «the rule that the hiring of personal services can only be made for a limited term as meaning that a contract of this nature cannot be made for the life of the employee, or for a period of time which would be equivalent to permanently. But the doctrine and jurisprudence has never understood that the

(1) Supreme Court, Asbestos Corporation Ltd v. Cook, 1933, C.L.R., 86.

(2) Supreme Court, Hanover Fire Insurance v. Stewart, 1936, C.L.R., 137. (3) This paragraph has been added by 13 Geo. VI

(4) Asbestos case, 91. hiring of personal services could not be made for an indefinite term. The only consequence of a contract of this sort is that one of the parties may free himself in giving a reasonable notice.

At the present time, hiring for an indefinite period is the normal method in business; wages are established by the week and, in industry, by the hour, the pay period is weekly or every two. weeks.

\section{II - Term of Notice}

One party may cancel at any time a labour contract, but to terminate it legally, there must, in principle, be a prior notice given to the other party by the one cancelling the contract. When must this notice be given and what is the term specified by the law, for the notice of termination of the contract? The answer varies with the duration of the contracts:

a) Contract on trial: This engagement, by its nature, may be cancelled at any time and without any prior notice, by one or the other of the parties.

b) Contract for a definite undertaking: This hiring out of services terminates with the completion of the work; the engagement of a hockey player finishes with the end of the season.

c) Contract for a definite period: The contract expires with the end of the term without the necessity of notice of termination. If on January 1st, 1949, I hired myself out for one year, my services automatically cease without notice on January 1st, 1950. But if the work continues, the contract renews itself automatically by tacit renewal and the term of notice is submitted to special rules which will be studied later.

d) Contract for an indefinite period: This contract was not provided for in the Code but has been recognized by the Courts. Judge Rinfret, decided in the Asbestos case (see above) that this contract could be cancelled by giving a reasonable notice.

Obviously, this concerns employees working regularly, permanent employees and not extra help or temporary labour for a definite or determinable period.

The rules established by the Code for the term of notice provided for the renting of property (C.C. art. 1642 and 1657) shall apply as suggested by the Supreme Court in the Hanover case (1936, C.L.R., 137). Let us quote these articles:

«1657. When the term of a lease is uncertain, or the lease is verbal, or presumed as provided in article 1608, neither of the parties can terminate it without giving notice 
to the other, with a delay of three months, if the rent be payable at terms of three or more months; if the rent be payable at terms of less than three months, the delay is to be regulated according to article 1642 .

The whole nevertheless subject to that article and to articles 1608 and 1653. 》

«1642. The lease or hire of a house or part of a house, when no time is specified for its duration, is held to be annual, terminating on the first day of May of each year, when the rent is at so much a year;

For a day, when it is at so much a day.

For a month, when it is at so much a month;

If the rate of the rent for a certain time be not shown, the duration of the lease is regulated by the usage of the place. »

The term of notice for the lease of houses is governed by the period of payment of the rent; in transposing these rules into the domain of the labour contract, the term of notice, in order to cancel the latter contract when it is for an indefinite period, would therefore be the pay period.

Consequently, the party causing the cancellation of such a contract must give to the other one, a prior notice equivalent to a pay period, that is, therefore, one month, one fortnight or one week.

It must be remembered that there is not always equivalence between the pay period and the method of its calculation. Employees may receive their pay monthly, weekly even though their remuneration is calculated by the hour, by the piece or on a commission basis. What the legislator took into consideration in order to determine the term of notice, is the pay period and not the method of calculating the wages. Thus an hourlypaid employee without a guarantee of work, may have the right to a term of notice of one week.

But in following this rule, it is necessary to remember that certain employees do not receive at each pay all that is due them. Thus, in addition to the periodical pay, they may be entitled to commissions, to annual-paid bonuses. It would then be necessary to consider that their wage is an annual wage as suggested by the Supreme Court in the Hanover case and that they would have the right to a term of notice of three months. (C.C. art. 1657).

A special system has been established for certain employees by the amendments made to article 1668 of the Civil Code, which we shall study later.

\section{e) Contract for a definite period, automa- tically prolonged:}

The contract concluded for a definite term renews itself automatically at its expiration for a period of the same duration, this is the tacit renewal provided for in article 1667 C. C. Let us quote Judge Rinfret in the Hanover case: ${ }^{5}$ «And if the contract was, as we decided (in the Asbestos case), for an indefinite period, there could be no question of tacit renewal. As a matter of fact, as Migneault points out in Droit Civil Canadien, Vol. 7, p. 371: "In order that there be tacit renewal, there must be an agreed or presumed term for the duration of the service.»

«The tacit renewal only takes place if the relations between the parties continue after the expiration of the date fixed in the lease of services; in the case of a lease for an indefinite period, there is no possibility of tacit renewal. 》

When does the labour contract prolonged by tacit renewal expire? It does not expire of course, it may terminate on the renewal date but on condition that a prior notice of termination has been given. Let us quote again Judge Rinfret in the Hanover case:

«But it also means that, once having been prolonged beyond the term originally fixed in the contract («terme conventionnel »), it was no longer a contract which, by its very terms, was to terminate at a fixed date mutually agreed upon; it became a contract which, by law, was presumed to be prolonged for another period of time fixed by the law itself, and with the proviso that it would terminate upon one or the other party giving a notice «within the delay required by the law ».

The labour contract subject to tacit renewal does not expire of course, it may only terminate on the renewal date, but on the express condition that prior notice has been given by the party cancelling the contract.

What is the term of the prior notice? We come back here to the rules in articles 1642 and 1657 , the term is still the pay period.

If the term of notice is the same for the fixedperiod contract which has been renewed, as for the contract of indefinite duration, the termination in the first case can only take place on the renewal date, in the second case, it may be at any time.

\section{f) Contract of employees mentioned in art- icle 1668:}

The legislator has added at the last Session, the following paragraph to article 1668 of the Civil Code:

«In the case of a domestic, servant, journeyman or labourer hired by the week, the month or the year, but for an indefinite period of time, his contract may be terminated by a notice given by one of the parties to the other, of a week, if the contract is by the week; of two weeks if the contract is by the month; of a month if the contract is by the year. $\gg$

(5) Id. 
This article does not apply to administration personnel, technicians, office employees, salesmen or to store clerks, but it governs maids, those in personal service of an employer as well as those doing manual labour, specialized or not, working in industrial, commercial or other establishments.

Article 1668 applies to the employees mentioned, contemplated therein only in so far as they are "hired by the week, the month or the year, but for an indefinite period of time. » The legislator does not necessarily consider the method of calculating the wage, e.g. those paid by the hour, by the day, on a piece-work basis, by lump sum or by commission and, consequently, this article governs these employees contemplated therein without consideration of the method of calculation of their pay, be it by the hour, on a piece-work basis or otherwise. Said article contemplates those who work from week to week, from month to month or even from year to year, i.e. those who have hired themselves for a fixed period e.g. week, month or year and of which the contract has been renewed by tacit renewal (C. C. art. 1667) and those of which the term of the contract, in place of a definite agreement, is presumed, according to the article 1642 of the Civil Code, to be the period of pay.

This amendment governs, therefore, employees who work regularly, employees having a steady job and not extra help called in to help during a rush period.

The employer of employees mentioned in article 1668 must, before dismissing them, give them a prior notice of a week, of two weeks or of a month.

In conflict with article 1667, article 1668 will take priority. If it appears that, although having agreed to a contract for a year, the parties intended to let it renew itself automatically, one of them could terminate it at any time with prior notice of one month. The employees mentioned in article 1668 cannot benefit from the advantages of the renewal provided for in article 1667.

\section{g) Other cases :}

The term of notice is therefore in relation to the duration of the labour contract. Quite often the term is definite; but, when it is not so, it is necessary to determine, according to the circumstances, what the parties intended to establish as term.

The foregoing rules govern principally those who have a regular job, those who are supposed to work every working-day. But in industry, many employees are called as extra labour to help during a rush period or to accomplish a definite task, e.g. unload a freight car. There are, therefore, cases where there is hiring for a fixed task or where there is hiring by the hour, in the latter case the term of notice being one hour.

$$
\text { III - Effects }
$$

No dismissal or quitting of work without prior notice, such as is provided for by the law, on behalf of the party who causes the termination of the contract, is the general rule. If the term of notice is not given or if it is not sufficient, the aggrieved party has the right to complain and claim from the other party the damages incurred. These damages for the employee represent ordinarily the wage that he would have earned during the term of notice. ${ }^{6}$

Here we do not admit the improper dismissal recognized in French law. Furthering the theory of the abuse of right, the French legislator considers that the employer, even while respecting the term of notice, may be in fault in dismissing an employee; He is obliged, in such a case, to pay the employee an indemnity which takes into account his age, his competence, his seniority, of the possibility of finding an identical place in the hierarchy of labour. (C. f. t. I, a. 23).

But the labour contract, just as any other agreement, may be cancelled with due cause, there is then no obligation for prior notice and there does not exist any appeal to the Court for the party aggrieved by the termination. Let us quote $\mathrm{Me}$ P. Beaulac ${ }^{8}$ :

"The dismissal of an employee may have been justified by his serious shortcomings. Such would be the case of an employee who would have got himself drunk during his working hours ${ }^{9}$, that of an editor of a newspaper who published articles contrary to the policy of the paper ${ }^{10}$, that of a clerk in a store who stayed away without permission ${ }^{11}$, that of a manager who would be guilty of insolence or insubordination to the directors of the company ${ }^{12}$, or who would have misappropriated money belonging to his employer ${ }^{13}$, that of

(6) P. Beaulac, La rupture du contrat de travail, $2 \mathrm{R}$.

(7) Précis de législation industrielle, 1947, Rouast \& Durand, No. 346 and following.

(8) Rupture du contrat de travail, 2 R. de B., 309.

(9) Prevost v. Standard Foundry \& Machinery Co. (1915)

(10) 21 Rélanger L., 433 . Bélanger (1895) 18 L. N., 354 or 24 S. C. R., 678.

(11) Charbonneau v. Benjamin, (1858) 2 J., 103.

(12) Dick v. Canada Jute Co. (1890) 34 J. 73 or (1890) 18 R. L., 555.

(13) Prevost v. Standard Foundry \& Machinery Co. quoted above. Webster v. G. T. R., (1857) 1 J. 223. 
the employee who refuses to be vaccinated as required by the law ${ }^{14}$, that of the salesman who, without good reason, refuses to make certain trips ${ }^{15}$. There is no question here of a term of notice.

\section{IV - Regulations}

What is the character of our legislation on the term of notice? We find it, let us not forget it, in the Civil Code under the title of contracts. And the regulations of the agreements established by the Code are only suppletory law; it only applies when the parties have not established conventionally another system, since there is no matter involved here concerning public order or good morals. (C. C. art. 13).

Consequently, the parties may freely establish the rules on term of notice and this conventional regulation overrules the suppletory regulations of the Code. Me P. Beaulac ${ }^{16}$ in his study, points out this rule very clearly: «In place of sufficient reason, it is necessary to have a notice of dismissal that conforms to the agreement expressed or implied between the parties. The regulations of the municipality, those of the industry or of the factory, the practice or the custom could, according to the case, supplement the agreement. »

The clauses established by the Masters and Servants Act (R.S.Q., 1941, ch. 328), carried a penal regulation, and therefore the rules were not within the powers of the parties to modify. If the employee left his employ without giving the notice provided in this statute, he could be brought before the Courts, fined and sent to prison; the contracting parties could not, because it was of public order, do away with the notice provided by this law. But the statute 13 Geo. VI, chapter 69 , has repealed this act ${ }^{17}$ and has introduced the clauses into the Civil Code.

(14) Archambault v. Gazette Printing Co. (1886) 9 L. N., 11.

(15) Prevost v. Gauthier (1878) 1 L. N., 289.

(16) 20., 308

(17) The Masters and Servants Act did not apply to the cities and towns that had passed regulations, covering the relations between masters and servants (Id. art. 2). The statute Geo. VI chapter 69 , has repealed not only this law but also the regulations
As a consequence, these clauses have lost their character of public order and have become suppletory law; they iherefore take effect only when there are no other contracted stipulations.

The term of notice is found to-day governed principally ${ }^{18}$ by the clauses expressed or implied of the labour contract (C. C. art. 1016).

As the clauses of the workshop agreement, what Me Beaulac calls usage, form part of the hiring contract, the regulations provided about the term of notice will be obligatory for the employees governed by it. Thus in certain industrial establishments, the employees, under the terms of internal rules, may be dismissed on an hour's notice.

The interpretation in the contracting domain of the regulations in respect to term of notice produces other consequences. The term of notice becomes a working condition which may be regulated by an ordinance of the Minimum Wage Commission ${ }^{19}$ or by a decree issued under the Collective Agreement Act ${ }^{20}$; such regulation have, under these Statutes, a character of public order.

In conclusion, as in France, the term of notice can now be made the object of the clause of the collective agreement of private order, as provided for under the Professional Syndicates Act, or that covered by the Labour Relations Act, or the Federal Code. This question, as well as others, may from now on become the object of negotiations between an employer and the accredited association of his employees, and be submitted to the consideration of an arbitration council constituted under the Quebec Trade Disputes Act or under even that of the Federal Conciliation and Labour Act.

adopted under it. Me. B. Pelletier, the solicitor of the City of Quebec, pretends that the regulation on this matter adopted by the City of Quebec, January 23rd, 1866, is still in force as it is the exercise of the powers granted by the Charter of the City of Quebec and not by the Masters and Servants Act.

(18) If one admits that the municipal regulations have been repealed by the Statute 13 Geo. VI, chapter 69 .

(19) R. S. Q., 1941, C. 164, art. 13.

(20) R. S. Q., 1941 , c. 163 , art. 10 